\title{
SURGICAL TREATMENT OF SUPRANUCLEAR AND INTERNUCLEAR OCULAR MOTILITY DISORDERS
}

\author{
S. A. BUCKLEY and J. S. ELSTON \\ Oxford
}

\begin{abstract}
SUMMARY
Patients with supranuclear and internuclear ocular motility disorders may have nystagmus and oscillopsia, or need to adopt an abnormal head posture to either fixate or maintain binocularity. Many have a cosmetically unsatisfactory appearance. In addition, because of lesions involving ocular motor nuclei or nerve fascicles, double vision is also a common problem. The usual management of these patients is symptomatic with occlusion or prisms. We report on 11 patients who underwent extraocular muscle surgery with the aim of reducing symptoms and restoring or improving binocular single vision. Three patients had bilateral internuclear ophthalmoplegia with exotropia, 3 had dorsal midbrain syndrome, 2 had residual upgaze palsies after cerebral vascular accidents, 2 had oculopalatal myoclonus and one skew deviation. After surgery, symptoms, visual function and cosmesis improved in nearly all patients. We recommend that surgery should be considered more readily in the rehabilitation of these patients.
\end{abstract}

In pure supranuclear ophthalmoplegia (e.g. gaze palsy) double vision is not a problem. However, unless the lesion responsible is highly selective and symmetrical, skew deviation (and diplopia) is common. Moreover, particularly with vascular occlusive pathology, multiple brainstem lesions are often present and elements of nuclear or infranuclear ophthalmoplegia evident. In internuclear ophthalmoplegia, both exodeviation and vertical (skew) deviation may cause diplopia.

Neuro-ophthalmic signs are important in the topical diagnosis of supranuclear palsy, but these patients usually present to physicians with symptoms such as vertigo and signs such as hemiparesis which may dominate the clinical picture. The patient will have a full neurological and medical investigation with neuroimaging. Underlying causes such as

From: Oxford Eye Hospital, Radcliffe Infirmary, Oxford, UK. Correspondence to: Miss S. A. Buckley, Grailing House, North Cowton, Northallerton, North Yorks DL7 0HF, UK. hypertension and diabetes in brainstem vascular disorders, or pineal tumours in dorsal midbrain syndrome, are treated.

The natural history of the eye movement dysfunction is determined principally by the aetiology and the amount of neuronal destruction. Diplopia, abnormal head postures adopted either to fixate or to minimise double vision, nystagmus and poor cosmesis may persist. ${ }^{1}$ More subtle disorders of eye movement such as saccade palsy may also be present. Patients with residual ocular motility problems are commonly managed conservatively with occlusion or prisms.

There are few reports of surgical intervention in these patients. Spielmann and Richter ${ }^{2}$ found that surgery in a case of dorsal midbrain syndrome improved both head posture and ocular motility. Botulinum toxin has also been used successfully in restoring normal eye position and movements in one patient with bilateral internuclear ophthalmoplegia and another with a persistent skew deviation. ${ }^{3}$

We report on the surgical results in 11 patients with supranuclear and internuclear motility disorders.

\section{PATIENTS, MATERIALS AND METHODS}

Eleven consecutive patients with supranuclear and internuclear ocular motility disorders were treated and surgery was only undertaken when assessments at 3-monthly intervals were stable, and the patient had undergone a trial of prism or occlusion treatment for both diplopia and abnormal head posture.

Intractable diplopia not relieved by prisms was the main complaint in patients suffering from bilateral internuclear ophthalmoplegia, skew deviation and some cases of predominantly dorsal midbrain syndrome. Problems with abnormal head posture due to neck extension were encountered primarily with upgaze palsies and dorsal midbrain syndrome. Discomfort and disabling symptoms from nystagmus and oscillopsia were the dominant symptoms with 
oculopalatal myoclonus. Surgery was undertaken to relieve the primary problem to aid in rehabilitation. The symptoms and objective of surgery are outlined in Table I. If there was a medical contraindication for general anaesthetic the surgery was performed under local anaesthetic.

All patients have been followed post-operatively for between 6 and 12 months.

\section{RESULTS}

The results of surgery are summarised in Table I.

In the majority of patients (Table I: cases $1-7,10$, 11), cosmetic appearance was improved by extraocular muscle surgery. After surgery, the large exodeviations of bilateral internuclear ophthalmoplegia (cases 5-7) were eliminated so that the eyes were straight in the primary position. The chin-up posture of the predominantly dorsal midbrain syndrome and upgaze palsies (cases $2-4,10,11$ ) was reduced so the patient could hold the head in a normal position.

Abnormal head posture was the simplest specific problem to solve with surgery. All four patients (cases 2, 3, 10, 11) with either dorsal midbrain syndrome or upgaze palsy had the abnormal head posture of chin elevation eliminated post-operatively. In dorsal midbrain syndrome relieving the abnormal head posture also reduced the discomfort from convergence retraction nystagmus on attempted upgaze.

Six patients (cases $1,4,5-7,11$ ) had surgery to relieve diplopia. This included one patient with a skew deviation, one with dorsal midbrain syndrome with exotropia, one with upgaze palsy with exotropia and three patients with bilateral internuclear ophthalmoplegia. Post-operatively the skew and dorsal midbrain syndrome required a small correction with prisms to relieve the diplopia, the upgaze palsy with exotropia required a large prismatic correction for near only, whereas the three bilateral internuclear ophthalmoplegia patients were orthophoric in the primary position. All three patients with bilateral internuclear ophthalmoplegia demonstrated normal or near-normal convergence with the successful realignment of their eyes. In one patient the benefit of surgery was compromised by nystagmus on attempted versions; in one, binocular single vision (BSV) in the primary position was accompanied by a small field of BSV in downgaze; the final patient regained nearly full versions and a large field of BSV.

The success of the surgery for oculopalatal myoclonus (cases 8,9 ) was more difficult to quantify. The amplitude of the vertical nystagmus was reduced after the surgery but still significant and causing troublesome symptoms. On being offered botulinum toxin after surgery, one patient refused but the other found that the combination of surgery and repeated injections of botulinum toxin much improved, though did not eradicate, his ocular motility problem.

During the follow-up period of 6-12 months there was no significant deviation from the immediate postoperative eye position. In cases 1 and 6 the area of BSV increased substantially in the first 6 months following surgery. In case 10 , who was aphasic following his cerebrovascular accident, the diplopia from pre-existing exotropia only became a problem for him when the profound head posture had been eliminated. This will require further surgery.

\section{DISCUSSION}

Many patients with supranuclear and internuclear ocular motility disorders are under the care of neurologists and neurosurgeons to whom they present with associated neurological problems such as hemiplegia. An analysis of the ocular motor deficits in the patients under review revealed that although the clinical picture was dominated by the primary diagnosis of supranuclear disorder, double vision was a common accompaniment. For example, in the three cases of dorsal midbrain syndrome of different aetiologies, exotropia was present and in one a skew deviation. Both cases of upgaze palsy were also divergent, but in all five cases adduction was full at the initial examination. The medial rectus subnuclei lie ventrally within the IIIrd nerve nuclei in close proximity to those prenuclear structures - the rostral interstitial nucleus of the median longitudinal fasciculus, the nucleus of Darkshevich and the interstitial nucleus of Cajal - known to be responsible for vertical gaze. The subnuclei, or structures responsible for normal vergence, may be involved contiguously or by separate lesions in the cases studied. In internuclear ophthalmoplegia with exotropia, adduction was defective.

Patients with supranuclear disorders can make a good overall improvement but may be handicapped by persistent eye problems which ophthalmologists may not realise are amenable to surgical treatment. We have shown that extraocular muscle surgery is useful in the rehabilitation of this group of patients.

Adjustable sutures were used in five of the six cases where diplopia was the prime problem. Adjustable sutures are recognised as useful in dysthyroid eye disease, infranuclear cranial nerve palsies and post-traumatic ocular motility problems $^{4-6}$ when accurate operative correction is required particularly for vertical deviations. Because of the disruption of normal ocular motor control in supra- and internuclear ophthalmoplegia, the effect of standard muscle surgery is unpredictable. Moreover, fusional amplitudes may have been damaged by the underlying disease process, making accurate post-operative alignment particularly important. Therefore in the management of this group of 
Table I. Summary of patients and results

\begin{tabular}{|c|c|c|c|c|c|}
\hline $\begin{array}{l}\text { Case and } \\
\text { diagnosis }\end{array}$ & Aetiology & $\begin{array}{l}\text { Pre-operative } \\
\text { assessment }\end{array}$ & $\begin{array}{l}\text { Objective of } \\
\text { surgery }\end{array}$ & Surgery & Overall outcome \\
\hline $\begin{array}{l}\text { Case } 1 \\
\text { Skew deviation }\end{array}$ & Tuberculous meningitis & $\begin{array}{l}\text { Right hypertropia of } \\
12 \text { PD not correctable } \\
\text { with prisms }\end{array}$ & $\begin{array}{l}\text { To relieve the } \\
\text { vertical diplopia }\end{array}$ & $\begin{array}{l}\text { Left IR recession on an } \\
\text { adjustable suture. LA }\end{array}$ & $\begin{array}{l}\text { BSV in the primary position } \\
\text { and downgaze. Vertical } \\
\text { diplopia for near of } 3 \text { PD } \\
\text { corrected with prisms }\end{array}$ \\
\hline $\begin{array}{l}\text { Case } 2 \\
\text { Dorsal midbrain } \\
\text { syndrome with } \\
\text { exotropia and } \\
\text { skew }\end{array}$ & $\begin{array}{l}\text { Head trauma during road } \\
\text { traffic accident }\end{array}$ & $\begin{array}{l}\text { Convergence } \\
\text { retraction nystagmus. } \\
\text { AHP with chin } \\
\text { elevation. Divergent } \\
\text { squint, } 1 / 3 \text { m } 25 \text { PD, } \\
6 \mathrm{~m} 40 \mathrm{PD}, \mathrm{L} / \mathrm{R} 6 \mathrm{PD} \text {. } \\
\text { No diplopia }\end{array}$ & $\begin{array}{l}\text { To relieve the } \\
\text { AHP, and improve } \\
\text { cosmesis }\end{array}$ & $\begin{array}{l}\text { Right MR resection, } \\
\text { and LR recession with } \\
\text { elevation of the } \\
\text { insertions. Left IR } \\
\text { resessions. GA }\end{array}$ & $\begin{array}{l}\text { AHP eliminated and } \\
\text { cosmesis improved. Small } \\
\text { RCS, } 1 / 3 \mathrm{~m} 6 \mathrm{PD}, 6 \mathrm{~m} 8 \text { PD. } \\
\text { No diplopia }\end{array}$ \\
\hline $\begin{array}{l}\text { Case } 3 \\
\text { Dorsal midbrain } \\
\text { syndrome with } \\
\text { exotropia }\end{array}$ & $\begin{array}{l}\text { Brainstem vascular } \\
\text { disease }\end{array}$ & $\begin{array}{l}\text { Convergence } \\
\text { retraction nystagmus. } \\
\text { AHP with chin } \\
\text { elevation. Variable } \\
\text { divergent squint of up } \\
\text { to } 25 \text { PD. Occasional } \\
\text { diplopia }\end{array}$ & $\begin{array}{l}\text { To relieve the } \\
\text { AHP }\end{array}$ & $\begin{array}{l}\text { Bilateral IR recessions. } \\
\text { GA }\end{array}$ & $\begin{array}{l}\text { AHP eliminated. Variable } \\
\text { diplopia and divergent } \\
\text { squint as pre-operatively }\end{array}$ \\
\hline $\begin{array}{l}\text { Case } 4 \\
\text { Dorsal midbrain } \\
\text { syndrome with } \\
\text { exotropia }\end{array}$ & Pineal tumour & $\begin{array}{l}\text { LDS, } 1 / 3 \mathrm{~m} 35 \mathrm{PD}, \\
6 \mathrm{~m} 20 \mathrm{PD} \text { with } \\
\text { diplopia. Very slow } \\
\text { upward eye } \\
\text { movements with } \\
\text { convergence } \\
\text { retraction mystagmus }\end{array}$ & To relieve diplopia & $\begin{array}{l}\text { Left } L R \text { recession and } \\
M R \text { resection. GA }\end{array}$ & $\begin{array}{l}\text { Small exotropia completely } \\
\text { controlled with } 8 \mathrm{PD} \text { prism }\end{array}$ \\
\hline $\begin{array}{l}\text { Case } 5 \\
\text { Bilateral INO } \\
\text { with exotropia }\end{array}$ & $\begin{array}{l}\text { Brainstem vascular } \\
\text { disease }\end{array}$ & $\begin{array}{l}\text { Constant diplopia. } \\
\text { Poor cosmesis with a } \\
\text { very large divergent } \\
\text { squint of } 70 \text { PD. } \\
\text { Nystagmus on all } \\
\text { versions }\end{array}$ & $\begin{array}{l}\text { To relieve the } \\
\text { diplopia and } \\
\text { improve cosmesis }\end{array}$ & $\begin{array}{l}\text { Bilateral MR resections } \\
\text { and LR recessions. One } \\
\text { lateral rectus on an } \\
\text { adjustable suture. GA }\end{array}$ & $\begin{array}{l}\text { Cosmesis excellent. } \\
\text { Nystagmus on all versions. } \\
\text { Binocularity limited to } \\
\text { primary position }\end{array}$ \\
\hline $\begin{array}{l}\text { Case } 6 \\
\text { Bilateral INO } \\
\text { with exotropia }\end{array}$ & $\begin{array}{l}\text { Brainstem vascular } \\
\text { disease }\end{array}$ & $\begin{array}{l}\text { Constant diplopia. } \\
\text { Poor cosmesis with a } \\
\text { large divergent squint } \\
\text { of around } 55 \text { PD }\end{array}$ & $\begin{array}{l}\text { To relieve the } \\
\text { diplopia and } \\
\text { improve cosmesis }\end{array}$ & $\begin{array}{l}\text { Bilateral MR resections } \\
\text { and LR recessions. One } \\
\text { lateral rectus on an } \\
\text { adjustable suture. LA }\end{array}$ & $\begin{array}{l}\text { Cosmesis excellent. No } \\
\text { diplopia with large area of } \\
\text { BSV }\end{array}$ \\
\hline $\begin{array}{l}\text { Case } 8 \\
\text { Oculopalatal } \\
\text { myoclonus }\end{array}$ & $\begin{array}{l}\text { CVA with right } \\
\text { hemiplegia and } \\
\text { dysphasia. Synchronous } \\
\text { palatal movements with } \\
\text { eye movements }\end{array}$ & $\begin{array}{l}\text { Bilateral large- } \\
\text { amplitude vertical eye } \\
\text { movements. Left gaze } \\
\text { palsy. Right INO. } \\
\text { Patient refused to } \\
\text { open eyes due to } \\
\text { discomfort from } \\
\text { extreme oscillopsia }\end{array}$ & $\begin{array}{l}\text { To relieve distress } \\
\text { from vertical eye } \\
\text { movements. } \\
\text { Amplitude too } \\
\text { great for botulinum } \\
\text { toxin }\end{array}$ & $\begin{array}{l}\text { Bilateral surgical } \\
\text { disinsertion and } \\
\text { extirpation of the } \\
\text { superior and inferior } \\
\text { rectus muscles. GA }\end{array}$ & $\begin{array}{l}\text { Moderate range of vertical } \\
\text { eye movements. } \\
\text { Spontaneous vertical } \\
\text { movements persist but of } \\
\text { reduced amplitude. } \\
\text { Declined botulinum toxin }\end{array}$ \\
\hline $\begin{array}{l}\text { Case } 9 \\
\text { Oculopalatal } \\
\text { myoclonus }\end{array}$ & $\begin{array}{l}\text { Brainstem vascular } \\
\text { disease }\end{array}$ & $\begin{array}{l}\text { AHP with chin down } \\
\text { and tilt to right. } \\
\text { Bilateral horizontal } \\
\text { gaze palsies. } \\
\text { Continuous vertical } \\
\text { large-amplitude } \\
\text { nystagmus. } \\
\text { Discomfort from } \\
\text { extreme oscillopsia }\end{array}$ & $\begin{array}{l}\text { To relieve large- } \\
\text { amplitude vertical } \\
\text { nystagmus }\end{array}$ & $\begin{array}{l}\text { Bilateral surgical } \\
\text { disinsertion and } \\
\text { extirpation of the } \\
\text { superior and inferior } \\
\text { rectus muscles. GA }\end{array}$ & $\begin{array}{l}\text { Moderate range of vertical } \\
\text { eye movements. Residual } \\
\text { vertical nystagmus partially } \\
\text { relieved by repeated } \\
\text { injections of botulinum } \\
\text { toxin }\end{array}$ \\
\hline $\begin{array}{l}\text { Case } 10 \\
\text { Upgaze palsy }\end{array}$ & $\begin{array}{l}\text { Brainstem vascular } \\
\text { disease }\end{array}$ & $\begin{array}{l}\text { Complete upgaze } \\
\text { palsy. Exodeviation. } \\
\text { AHP with chin } \\
\text { elevation and turn to } \\
\text { right }\end{array}$ & $\begin{array}{l}\text { To relieve the } \\
\text { AHP }\end{array}$ & $\begin{array}{l}\text { Right inferior rectus } \\
\text { recession. LA }\end{array}$ & $\begin{array}{l}\text { Moderate LDS } 35 \text { PD. AHP } \\
\text { much improved, but patient } \\
\text { now complaining of } \\
\text { diplopia. On waiting list for } \\
\text { left LR recession under LA }\end{array}$ \\
\hline $\begin{array}{l}\text { Case } 11 \\
\text { Upgaze palsy }\end{array}$ & Multiple CVAs & $\begin{array}{l}\text { Left homonymous } \\
\text { hemianopia. Upgaze } \\
\text { palsy with exo- } \\
\text { deviation of } 25 \text { PD. } \\
\text { AHP with chin } \\
\text { elevation. Diplopia in } \\
\text { all positions }\end{array}$ & $\begin{array}{l}\text { To relieve the } \\
\text { AHP and diplopia }\end{array}$ & $\begin{array}{l}\text { Bilateral inferior rectus } \\
\text { recession and right } \\
\text { lateral rectus recession } \\
\text { on an adjustable suture. } \\
\text { LA }\end{array}$ & $\begin{array}{l}\text { AHP eliminated. } \\
\text { Orthophoric for distance } \\
\text { with no diplopia. Moderate } \\
\text { exotropia ( } 35 \text { PD) with } \\
\text { diplopia for near }\end{array}$ \\
\hline
\end{tabular}

PD, prism dioptres; INO, internuclear ophthalmoplegia; L/R, left over right (left hypertropia); LA, local anaesthetic; GA, general anaesthetic; IR, inferior rectus; MR, medial rectus; LR, lateral rectus; BSV, binocular single vision; AHP, abnormal head posture; LDS, left divergent squint; RCS, right convergent squint; CVA, cerebral vascular accident. 
patients, the adjustable suture technique is also useful.

If a patient for extraocular muscle surgery is considered a poor risk for general anaesthetic, adjustable suture surgery can be quite adequately performed under local anaesthetic. ${ }^{7}$ However, when considering local anaesthesia as an option, we advise an operation using muscle recessions rather than muscle resections, which can be uncomfortable for the patient (case 6).

In two cases (1 and 6) a surprisingly large area of BSV was gained during the first 6 months postoperatively. All patients with bilateral internuclear ophthalmoplegia with exotropia regained convergence which had been absent in the preoperative assessments of eye movements. Usually with unilateral internuclear ophthalmoplegia, normal medial rectus activity is observed on convergence. The large exotropia of our patients with bilateral internuclear ophthalmoplegia may have inhibited the ability of these undamaged neuronal circuits to function properly. It was only by realigning the eyes that the function of convergence could be realised. Spielmann and Richter ${ }^{2}$ also found afer extraocular surgery on a boy with Parinaud's syndrome, that ocular motility improved beyond their expectations. They postulated that the surgery had allowed their patient to use undamaged neuronal circuits to achieve the increased ocular motility. Similarly in cases 1 and 6 it would appear that the surgical intervention facilitated surviving supranuclear control neuronal elements to operate and create a large area of BSV.

The marked vertical eye movements from oculopalatal myoclonus are a more difficult problem. It was felt that the large amplitude of the nystagmus was too great for botulinum toxin to reduce without probable involvement of the levator muscle causing a ptosis. The problem was therefore tackled by surgical disinsertion and oversewing into Tenon's capsule of the vertical recti muscles, with a view to possibly augmenting the results with botulinum toxin postoperatively. In both cases the amplitude of the vertical eye movements was reduced by the surgery though there was still significant oscillopsia. One patient accepted post-operative botulinum toxin with a subjective partial improvement in symptoms, maintained by repeated injections. Surgery would appear to be least successful in this group but may still have a role to play in alleviating a degree of the troublesome symptoms.

In summary, we have shown that extraocular muscle surgery has something to offer in resolving the symptoms of diplopia, abnormal head postures and poor cosmesis. Supranuclear and internuclear disorders can present with a variety of complicated ocular motility problems. Surgery is unlikely to restore normal ocular movements but identification of the dominant problem for these patients can then allow one to decide the most appropriate surgery for either restoration of BSV or alleviation of abnormal head postures. This will then help in the rehabilitation of other neurological problems such as hemiplegia and co-ordination difficulties. Improved cosmesis aids social interactions and employment prospects. Although the majority of our patients had surgery under a general anaesthetic, local anaesthetic squint surgery is possible if general anaesthesia is contraindicated, and these patients should not be excluded from treatment.

Key words: Supranuclear ocular motility disorder, Binocular single vision, Surgery.

\section{REFERENCES}

1. Gonyea EF. Bilateral internuclear ophthalmoplegia: association with occlusive cerebrovascular disease. Arch Neurol 1974:31:168-73.

2. Spielmann A, Richter J. Oculomotor surgery in Parinaud's syndrome. Ophtalmologie 1989;3(2):157-9.

3. Newman NJ, Scott RL. Botulinum toxin treatment of supranuclear ocular motility disorders. Neurology 1992:42:1391-3.

4. Jampolsky AJ. Strabismus reoperation techniques. Trans Am Acad Ophthalmol Otolaryngol 1975;79: 704-17.

5. Lee J, O'Day J, Fells P. Early experience with adjustable squint surgery at Moorfields Eye Hospital with long term follow up. Trans Ophthalmol Soc UK 1985;104:662-74.

6. Franklin S, Hiatt RL. Adjustable sutures in strabismus surgery. Ann Ophthalmol 1989;21:285-9.

7. Ruben ST, Elston JS. One stage adjustable sutures: practical aspects. Br J Ophthalmol 1992;76:675-7. 